Article

\title{
Optimizing Nitrogen Application for Growth and Productivity of Pomegranates
}

\author{
Silit Lazare ${ }^{1, *,+}\left(\mathbb{0}\right.$, Yang Lyu ${ }^{1,2,+}$, Uri Yermiyahu ${ }^{1}$, Yehuda Heler ${ }^{1,3}$, Alon Ben-Gal ${ }^{1}{ }^{\oplus}$, \\ Doron Holland ${ }^{4}$ and Arnon Dag ${ }^{1}$ \\ 1 Gilat Research Center, Agricultural Research Organization, The Volcani Center, Gilat, M.P. \\ Negev 8528000, Israel; lyu.yang.china@gmail.com (Y.L.); uri4@volcani.agri.gov.il (U.Y.); \\ yehuda.heler@mail.huji.ac.il (Y.H.); bengal@volcani.agri.gov.il (A.B.-G.); arnondag@volcani.agri.gov.il (A.D.) \\ College of Resources and Environmental Sciences, China Agricultural University, Beijing 100193, China \\ 3 Institute of Plant Sciences and Genetics in Agriculture, The Robert H. Smith Faculty of Agriculture, Food and \\ Environment, The Hebrew University of Jerusalem, Rehovot 7610001, Israel \\ 4 Institute of Plant Sciences, Agricultural Research Organization, Newe Ya'ar Research Center, \\ Ramat Yishay 30095, Israel; vhhollan@volcani.agri.gov.il \\ * Correspondence: silitl@volcani.agri.gov.il \\ + Equal contribution.
}

Received: 9 February 2020; Accepted: 4 March 2020; Published: 6 March 2020

check for updates

\begin{abstract}
Quantification of actual plant consumption of nitrogen $(\mathrm{N})$ is necessary to optimize fertilization efficiency and minimize contamination of earth resources. We examined the performance of fruit-bearing pomegranate trees grown in soilless media and exposed to eight $\mathrm{N}$-fertigation treatments, from 5 to $200 \mathrm{mg} \mathrm{N} \mathrm{L}^{-1}$. Reproductive and vegetative indices were found to be optimal when 20 to $70 \mathrm{mg} \mathrm{N} \mathrm{L}^{-1}$ was supplied. Nitrogen application levels over $70 \mathrm{mg} \mathrm{L}^{-1}$ reduced pomegranate development and reproduction. $\mathrm{N}$ uptake in low-level treatments was almost $100 \%$ and decreased gradually, down to $13 \%$ in $200 \mathrm{mg} \mathrm{N} \mathrm{L}^{-1}$ treatment. $\mathrm{N}$ usage efficiency was maximized under $20 \mathrm{mg} \mathrm{N} \mathrm{L}^{-1}$, in which case $80 \%$ to $90 \%$ of added $\mathrm{N}$ was taken up by the trees. At high $\mathrm{N}$ application, its efficiency was reduced with less than $50 \%$ utilized by the trees. Leaf $\mathrm{N}$ increased to a plateau as a function of increasing irrigation solution $\mathrm{N}$, maximizing at $\sim 15$ to $20 \mathrm{mg} \mathrm{N} \mathrm{g}^{-1}$. Therefore, analysis of diagnostic leaves is not a valid method to identify excessive detrimental $\mathrm{N}$. The results should be valuable in the development of efficient, sustainable, environmentally responsible protocols for $\mathrm{N}$ fertilization in commercial pomegranate orchards, following adaptation and validation to real soil field conditions.
\end{abstract}

Keywords: fertigation; NUE; uptake; yield; vegetative indices; reproductive indices

\section{Introduction}

Nitrogen $(\mathrm{N})$ is a major nutritional element in plants, required in many physiological and developmental processes such as photosynthesis [1], metabolite biosynthesis [2,3] and flowering [4]. Most $\mathrm{N}$ uptake in fruit trees occurs during the intensive vegetative growth and post-harvest phases [5]. Diagnostic leaves, which are commonly used for nutritional status evaluation of fruit trees [6-8], are sampled following this seasonal pattern. Nitrogen use efficiency (NUE) is of significant concern in horticulture. Appropriate and efficient $\mathrm{N}$ application promotes yields, profits and environmental sustainability. Nitrogen pollution of drinking water resources, originating from agricultural systems, is a major problem due to health risks $[9,10]$. Leaching from agriculture in general, and orchards specifically, has been reported to be a significant contributor to a growing global phenomenon of contamination of groundwater with nitrogen [11-13]. 
Historically, there has been a common agricultural belief that increased applications of $\mathrm{N}$ result in higher and better yields. This perception has been refuted in several species, among them olive [14,15], citrus [16] and apple [17], all showing optimum production response functions, whereas excess $\mathrm{N}$ lead to reduced quantity and quality of yields. A recent study in almonds revealed that excessive $\mathrm{N}$ interferes with photosynthesis [18]. An accurate means to prevent excessive $\mathrm{N}$ fertilization in horticultural systems are, therefore, needed. Traditionally, assessing the $\mathrm{N}$ status of the plant is done by leaf mineral analysis, but this method is often inaccurate under conditions of excessive N [19]. Another standard method to estimate plant $\mathrm{N}$ status is through the measurement of chlorophyll content, as $\mathrm{N}$ is the main mineral needed for chlorophyll biosynthesis. When using chlorophyll fluorescence as the indicator, extreme $\mathrm{N}$ levels are again problematic, as the molecule is saturated [20].

Pomegranate (Punica granatum L., Punicaceae) is a domesticated fruit tree with relatively short juvenility [21] and fruit with high nutritional and economic value [22]. Pomegranates were traditionally cultivated in Africa and Asia [23], but a growing concept of the health benefits from its juice has led to growth in both global demand and production area. According to recent estimations, from 2014 to 2025, the area under pomegranate cultivation will increase ten-fold [24]. Most recent studies on pomegranates have focused on fruit characteristics. However, the scientific base for the agronomic requirements of the crop is still vague, and professional empirical recommendations are limited.

Pomegranate is considered drought resistant, as it can thrive in arid and semiarid regions [25]. Drip irrigation has been found to promote pomegranate vegetative growth and productivity [26]. Water deficit can negatively influence fruit color and metabolic characteristics [27]. Fertilization recommendations for pomegranate cultivation vary according to tree age, region, climate, and fruit load. For example, in Spain, pomegranates are not fertilized unless deficiency symptoms appear [28]. In California, the estimated tree demand is 60 to $112 \mathrm{~kg} \mathrm{~N}$ ha $^{-1}$ year $^{-1}$ [29], and in Israel, the annual recommendation for growers is $200 \mathrm{~kg} \mathrm{~N}$ ha-1 [23]. The Californian and Israeli values are similar, as fruit trees grown under field conditions are known to consume less than $55 \%$ of the $\mathrm{N}$ supplied in fertilization [30], which means low $\mathrm{N}$ efficiency and high waste. Several recent studies have dealt with the effect of $\mathrm{N}$ on pomegranate growth. One study found that the more $\mathrm{N}$ supplied to the tree, the larger it grows and the more fruit it yields [31], but in other studies, no consistent response has been found between yield and increased $\mathrm{N}$ rate [29,32].

In order to improve knowledge regarding $\mathrm{N}$ requirements of bearing pomegranate trees, we exposed individual trees to elevated levels of $\mathrm{N}$ with irrigation water and following their vegetative and reproductive performance. As opposed to other studies which have been conducted in mature orchards where the soil contributes greatly to mineral supply, our research was conducted on bearing trees grown in a soilless medium, where fertilizer was supplied via an irrigation (fertigation) system. This system allowed accurate monitoring of tree water and nutrient consumption and enabled direct insights regarding physiological responses to $\mathrm{N}$ availability [14].

\section{Materials and Methods}

\subsection{Plant Material and Experimental Design}

Two-year-old pomegranate "Wonderful" plants were transplanted into containers in July 2015, at the Gilat Research Center, Agricultural Research Organization, Israel. Each tree grew in a $500 \mathrm{~L}$ container filled with perlite (212, Agrekal, Israel). Eight different $\mathrm{N}$ levels were set as 5, 10, 20, 40, 70, 100,150 , and $200 \mathrm{mg} \mathrm{L}^{-1} \mathrm{~N}\left(90 \% \mathrm{NO}_{3}{ }^{-}\right.$and $\left.10 \% \mathrm{NH}_{4}{ }^{+} \mathrm{w} / \mathrm{w}\right)$ in the irrigation water. A randomized block design was used, with four replications, i.e., four trees per treatment. Additional nutrients were supplied through the fertigation system as follows: phosphorus (P) $10 \mathrm{mg} \mathrm{L}^{-1}$, potassium (K) $100 \mathrm{mg} \mathrm{L}^{-1}$, calcium (Ca) $50 \mathrm{mg} \mathrm{L}^{-1}$, magnesium (Mg) $24 \mathrm{mg} \mathrm{L}^{-1}$, sulphur (S) $84 \mathrm{mg} \mathrm{L}^{-1}$, iron (Fe) $550 \mu \mathrm{g} \mathrm{L}{ }^{-1}$, manganese (Mn) $250 \mu \mathrm{g} \mathrm{L}{ }^{-1}$, zinc (Zn) $125 \mu \mathrm{g} \mathrm{L}^{-1}$, copper $(\mathrm{Cu}) 19.0 \mu \mathrm{g} \mathrm{L}^{-1}$, molybdenum (Mo) $13.5 \mu \mathrm{g} \mathrm{L}^{-1}$ and boron (B) $190 \mu \mathrm{g} \mathrm{L}^{-1}$. Nutrient solutions were prepared in $1500 \mathrm{~L}$ containers with concentrations monitored and maintained in the range of $90 \%$ to $110 \%$ of target values. Target nutrient 
concentrations were achieved by proportionally dissolving salts of: $\mathrm{KCl}, \mathrm{KH}_{2} \mathrm{PO}_{4}, \mathrm{NH}_{4} \mathrm{H}_{2} \mathrm{PO}_{4}, \mathrm{KNO}_{3}$, $\mathrm{NaNO}_{3}, \mathrm{MgSO}_{4}$, and $\mathrm{NH}_{4} \mathrm{NO}_{3}$. Micro-nutrients were supplied as BAR-KORET solution (ICL, Israel). Between July 2015 and February 2016, all trees were fertigated with $70 \mathrm{mg} \mathrm{N} \mathrm{L}{ }^{-1}$. Differential fertilization treatments started in March 2016. Growth and reproductive indices were evaluated during 2016,2017 , and 2018. The volume of water draining from the containers was measured weekly. The trees were irrigated and fertigated daily and excessively at rates designed to achieve $30 \%$ leaching fraction.

\subsection{Growth Indices}

Trunk diameter was measured four times a year, in January, April, July, and October, using a Vernier caliper, at a marked point $20 \mathrm{~cm}$ above the perlite surface. Leaf area density $\left(\mathrm{m}^{2}\right.$ leaf area per $\mathrm{m}^{2}$ surface area) was measured by a portable leaf area meter (Accupar LP-80). The sensor was placed at a single point, on the perlite surface, close to the trunk. Canopy size was calculated as the volume (V) of an ellipse where

$$
\mathrm{V}=((4 \pi \times \mathrm{abc}) / 3) / 2
$$

and " $a$ " and " $b$ " were the radius of canopy's circumference $30 \mathrm{~cm}$ above the trunk (a and b were equal in our trees), and " $\mathrm{c}$ " was the height of the tree. The trees were pruned twice during the experiment, after leaf drop in February 2017 and 2018, and pruned branches were weighed. Trees were topped $2 \mathrm{~m}$ above the perlite surface, keeping 3 to 4 main outward-growing branches only. All stem-sprouting branches were removed.

\subsection{Water Consumption and Nutrient Uptake}

The amount of applied irrigation water was based on a $30 \%$ leaching fraction in each treatment, separately. Drainage volume was measured and recorded once a week, while the mineral concentration of irrigation solution and drainage was measured every month. The uptake of water and nutrients was calculated as the difference between the irrigation solution and drainage.

\subsection{Leaf Analyses}

Chlorophyll content was assessed in the youngest fully developed ("diagnostic") leaves with a chlorophyll meter (SPAD-502, Minolta, Osaka, Japan). Thirty leaves were measured from each tree in June of each year. Twenty diagnostic leaves were sampled from each tree during extensive growth and full bloom (May) and preharvest (September) every year, to evaluate the $\mathrm{N}$ status of the tree. As "Wonderful" is a late-ripening cultivar [33], and harvest takes place just before leaf fall, we could not sample the leaves postharvest, and followed the extension services guidance. The leaves were washed, dried at $70^{\circ} \mathrm{C}$ and ground to powder. Total $\mathrm{N}$ concentration was determined after digestion with sulfuric acid and hydrogen peroxide. The concentrations of $\mathrm{N}$ were determined with an auto analyzer (Lachat Instruments, Milwaukee, Wisconsin, USA). Six average size full-grown leaves were taken from every tree in May 2018; the area of each leaf was measured by Easy Leaf Area [34] from digital photographs.

\subsection{Nitrogen Use Efficiency}

The use efficiency of $\mathrm{N}$ was defined alternatively as:

PFP Partial factor productivity of applied N = fruit yield (of the treatment)/ $\mathrm{N}$ application amount;

NUpE Nitrogen uptake efficiency $=\mathrm{N}$ uptake (of the treatment)/ $\mathrm{N}$ application;

NUtE Nitrogen utilization efficiency = fruit yield (of the treatment)/N uptake;

Nitrogen uptake was calculated as the mass balance difference between the irrigation solution and drainage. 


\subsection{Statistical Analyses}

Data were analyzed by least squares fitting and determined as nonlinear regression functions in GraphPad Prism (GraphPad Software Inc., USA). The significant differences of $8 \mathrm{~N}$ levels were determined using one-way ANOVA and tested by Tukey's honest significance test in JMP 13.2 software. Differences between different months and years for each $\mathrm{N}$ level were tested by student's $\mathrm{t}$-test (SAS Institute Inc, Cary, NC, USA). $p \leq 0.05$ was considered significant.

\section{Results}

\subsection{Nitrogen Concentration in the Plant}

Nitrogen treatments affected the $\mathrm{N}$ concentration in diagnostic leaves significantly (Figure 1). The response curve reached maximum values at irrigation levels of 40 to $70 \mathrm{mg} \mathrm{N} \mathrm{L}^{-1}$ during all three years tested. Significant differences were found when leaves were sampled on different dates. Leaf N concentration was lower in September as compared with May in each year. The most considerable difference between sampling dates was in 2017 (Figure 1B). During 2016, no significant difference was found in leaf $\mathrm{N}$ when the tree was given $70 \mathrm{mg} \mathrm{L}^{-1}$ and above (Figure 1A). This phenomenon was similar for the September samplings of 2017 and 2018, but in May, significant fluctuations were recorded. Generally, for the low $\mathrm{N}$ application level treatments, $\mathrm{N}$ concentration in the leaves was distinct during all three years. Still, for the high-level treatments, there were almost no significant differences between the treatments or between the years. The maximal measured leaf $\mathrm{N}$ concentration was $\sim 20 \mathrm{mg} \mathrm{g}^{-1}$, during May 2017, and the minimal was $\sim 7.5 \mathrm{mg} \mathrm{g}^{-1}$, during September 2017. In most cases, 2017 and 2018 values were higher than those of 2016.

Nitrogen levels in irrigation water affected leaf indices significantly (Figure 2). The most considerable differences were found between the low-level treatments, where each increase in $\mathrm{N}$ resulted in a significant rise in leaf chlorophyll content (Figure 2A). The responses remained stable after $40 \mathrm{mg} \mathrm{N} \mathrm{L}^{-1}$ (Figure 2A). During 2017 and 2018, no significant difference was found between this treatment and 70,100, or $150 \mathrm{mg} \mathrm{N} \mathrm{L}^{-1}$ with leaf chlorophyll stabilizing at $\sim 55$ and $\sim 65$ SPAD units, respectively. The lowest chlorophyll content was found in leaves of trees receiving $5 \mathrm{mg} \mathrm{N} \mathrm{L}^{-1}$. Leaf color is a consequence of chlorophyll content, which was measured by the SPAD (Figure 2A), but we could also see it visually, as the leaves of high-level treatments were darker than those of low-level N (Figure 2B). A comparison of leaf size and color, in 2018, revealed an evident influence of $\mathrm{N}$ level over this organ (Figure 2B); the smallest leaf area measured in treatments 5 and $20 \mathrm{mg} \mathrm{N} \mathrm{L}^{-1}$, and the largest in the $100 \mathrm{mg} \mathrm{N} \mathrm{L}^{-1}$ treatment. 


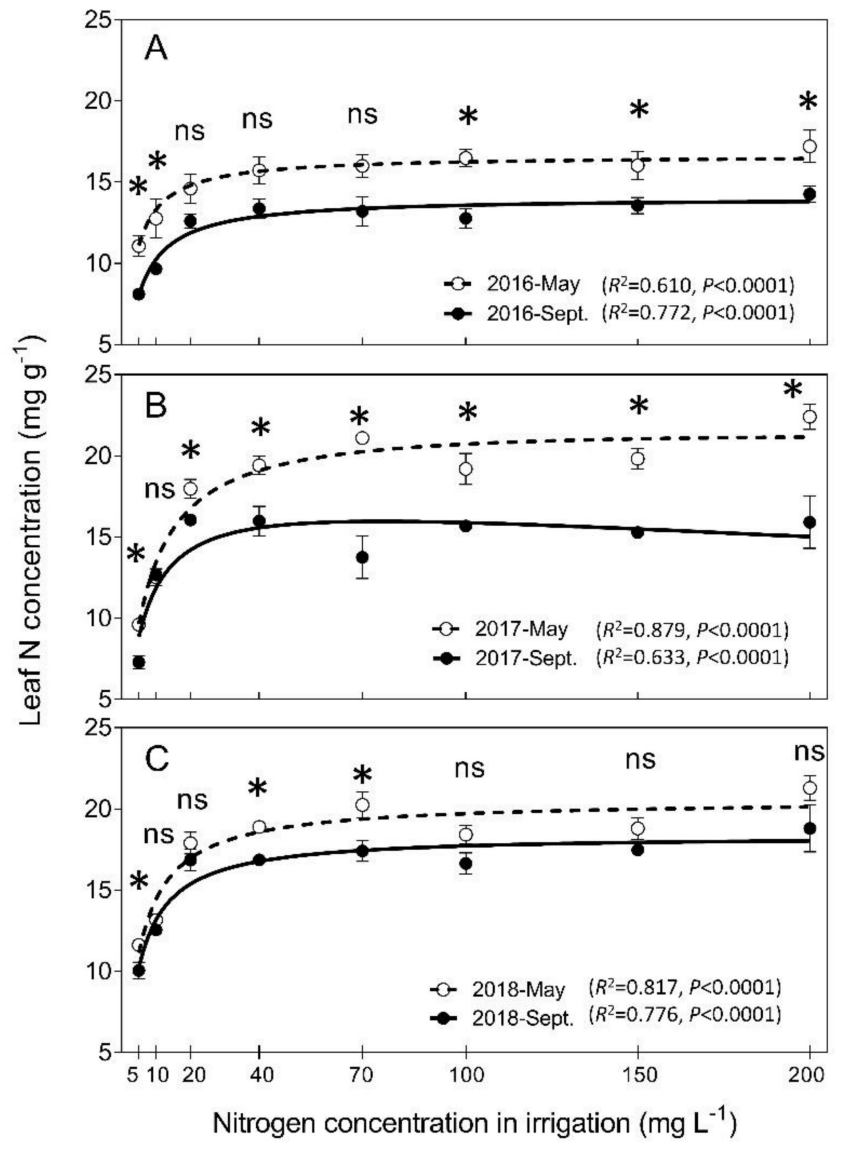

Figure 1. Nitrogen concentration in the leaves of pomegranate trees, as a function of fertigation $\mathrm{N}$ levels. (A) 2016; (B) 2017; (C) 2018. ns = not significant. Bars represent standard deviation (SD). Asterisk (*) defines a significant difference between the dates, at the same $\mathrm{N}$ level. The line represents best fit regression. Regression line equations are presented in Table A1. Significance between treatments at each sampling date is presented in Table A2.

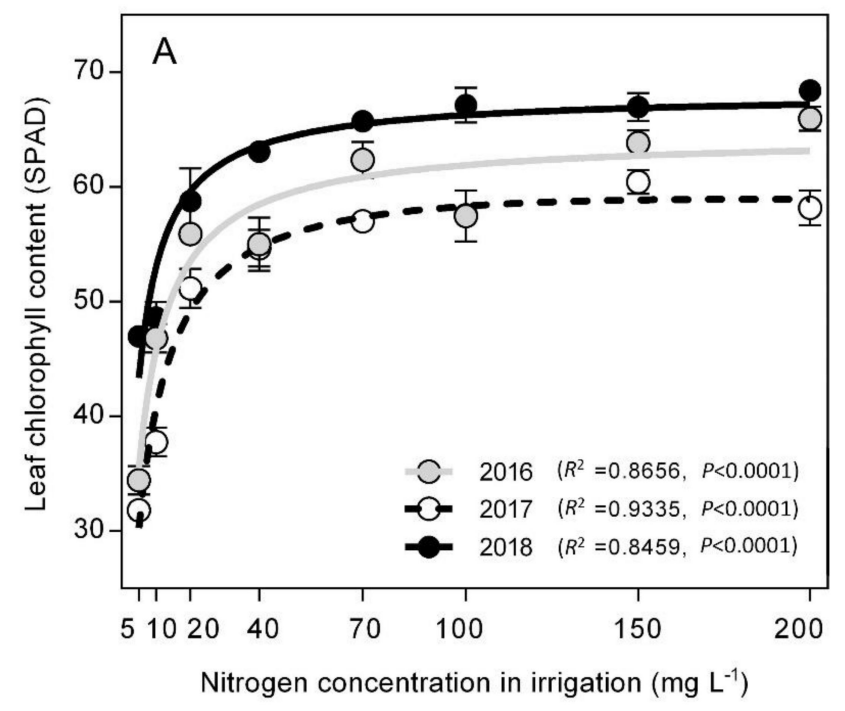

\begin{tabular}{cc}
\hline $\begin{array}{c}\mathrm{B} \\
\begin{array}{c}\mathrm{N} \\
\text { concentration } \\
\left(\mathrm{mg} \mathrm{L}^{-1}\right)\end{array}\end{array}$ & $\begin{array}{c}\text { Leaf } \\
\text { area } \\
\left(\mathrm{cm}^{2}\right)\end{array}$ \\
\hline 5 & $6.6 \mathrm{E}$ \\
\hline 10 & $9.0 \mathrm{D}$ \\
\hline 20 & $6.9 \mathrm{E}$ \\
\hline 40 & $11.8 \mathrm{C}$ \\
\hline 70 & $13.1 \mathrm{~B}$ \\
\hline 100 & $16.2 \mathrm{~A}$ \\
\hline 150 & $13.5 \mathrm{~B}$ \\
\hline 200 & $14.2 \mathrm{~B}$ \\
\hline
\end{tabular}

Figure 2. Leaf indices in pomegranate trees as a function of nitrogen concentration in the irrigation solution. (A) Leaf chlorophyll content; (B) leaf size and color in 2018. Bars represent SD. Different letters represent significant differences between treatments at a given sampling date. Regression equations and statistics are presented in Tables A1 and A2. 


\subsection{Vegetative Growth Indices}

Canopy volume increased significantly from 2017 to 2018 for all N treatments (Figure 3A). In both years, the lowest volume was measured for trees receiving $5 \mathrm{mg} \mathrm{N} \mathrm{L}^{-1}$, and volume increased gradually with $\mathrm{N}$ concentration. The greatest canopy volume was measured for the $40 \mathrm{mg} \mathrm{N} \mathrm{L}^{-1}$ treatment during 2018. It increased 3.4 times $\left(7.6 \mathrm{~m}^{3}\right.$ to $\left.26.2 \mathrm{~m}^{3}\right)$ in one year. Higher $\mathrm{N}$ levels were not significantly different from those found in the $40 \mathrm{mg} \mathrm{N} \mathrm{L}^{-1}$ treatment in 2017, but during 2018 they resulted in lower canopy volume and gradually declining response curves (Figure 3A). During 2017, pruning material weight was similar among the treatments (Figure 3B). In 2018, the greatest weight was measured under $70 \mathrm{mg} \mathrm{N} \mathrm{L}^{-1}$, and the peak of the best-fit regression curve corresponded to $40 \mathrm{mg} \mathrm{N} \mathrm{L}^{-1}$ (Figure 3B). Leaf area density increased significantly from 2016 to 2017 at all $\mathrm{N}$ levels, except for $5 \mathrm{mg} \mathrm{N} \mathrm{L}^{-1}$ (Figure 3C). There was no significant difference between 2017 and 2018 in this parameter, in contrast with the other indices presented, and again, the peak corresponded to $40 \mathrm{mg} \mathrm{N} \mathrm{L}^{-1}$. Highest annual water consumption was recorded for trees receiving $70 \mathrm{mg} \mathrm{N} \mathrm{L}^{-1}$ during 2016 (6.2 $\mathrm{m}^{3}$ per tree), but in 2017 and 2018, $40 \mathrm{mg} \mathrm{N} \mathrm{L}^{-1}$ was the treatment with the highest amount of water consumed, $11.6 \mathrm{~m}^{3}$ per tree and $18.9 \mathrm{~m}^{3}$ per tree, respectively (Figure 3D). The lowest annual water consumption was for the $5 \mathrm{mg} \mathrm{N} \mathrm{L}^{-1}$ treatment for all three years. The response curve for 2018 peaks at around $40 \mathrm{mg} \mathrm{N} \mathrm{L}^{-1}$ and then declines noticeably, similarly to that of canopy volume (Figure 3A).
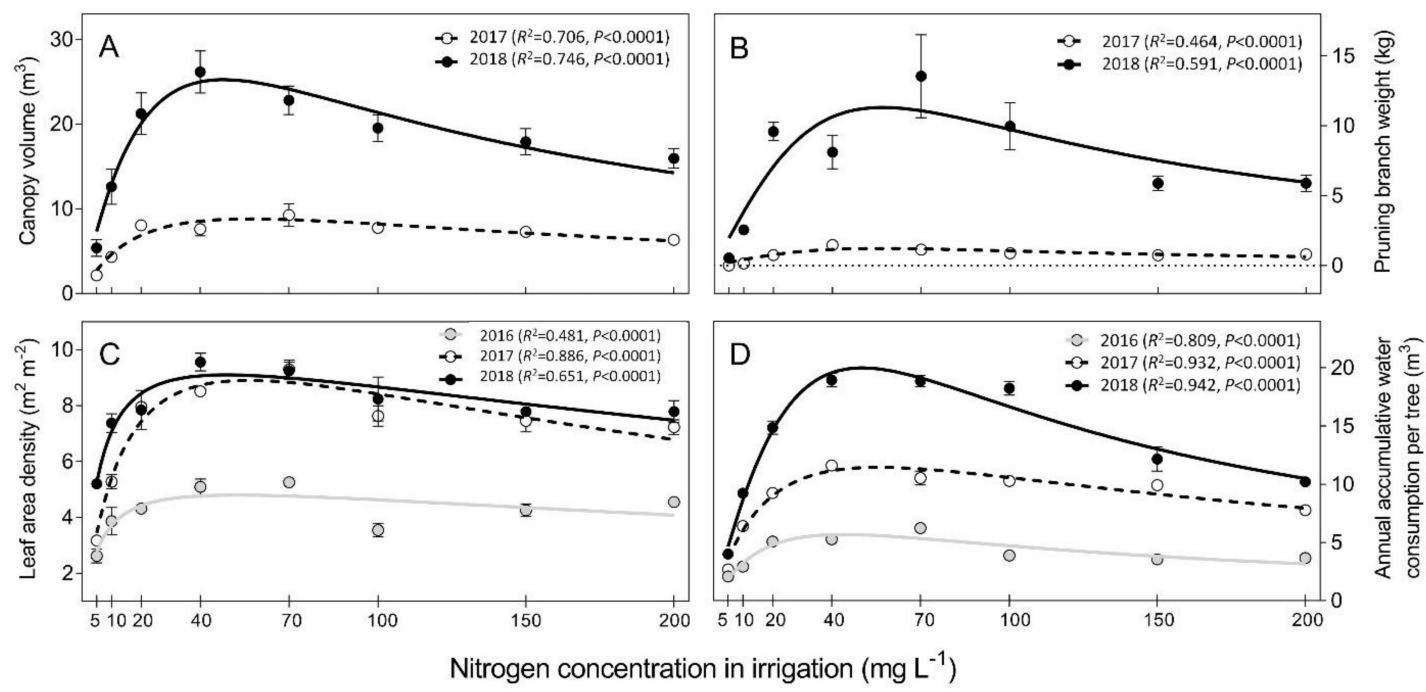

Figure 3. Growth indices for pomegranate trees as a function of nitrogen concentration in the irrigation solution. (A) Canopy volume; (B) branch weight; (C) leaf density; (D) accumulated water consumption. Bars represent SD. Regression line equations are presented in Table A1. Significance between treatments at a given sampling date is presented in Table A2.

Trunk diameter increased gradually over three years for all treatments (Figure 4). During the first year, the greatest growth was that of treatments 70 and $100 \mathrm{mg} \mathrm{N} \mathrm{L}^{-1}$ (329\% and 310\%, respectively), but in the third year, trees receiving $40 \mathrm{mg} \mathrm{N} \mathrm{L}^{-1}$ had the highest growth rate (Table 1). At the end of the experiment, the lowest change, $361 \%$, was recorded for the $5 \mathrm{mg} \mathrm{N} \mathrm{L}^{-1}$ treatment, while the highest, $621 \%$, was measured in trees of the $70 \mathrm{mg} \mathrm{N} \mathrm{L}^{-1}$ treatment. The most excessive $\mathrm{N}$ treatment, $200 \mathrm{mg} \mathrm{N} \mathrm{L}^{-1}$, had the third lowest change, similar to that of the $10 \mathrm{mg} \mathrm{N} \mathrm{L}^{-1}$ treatment. The most considerable growth occurred during the first year, in all treatments. 


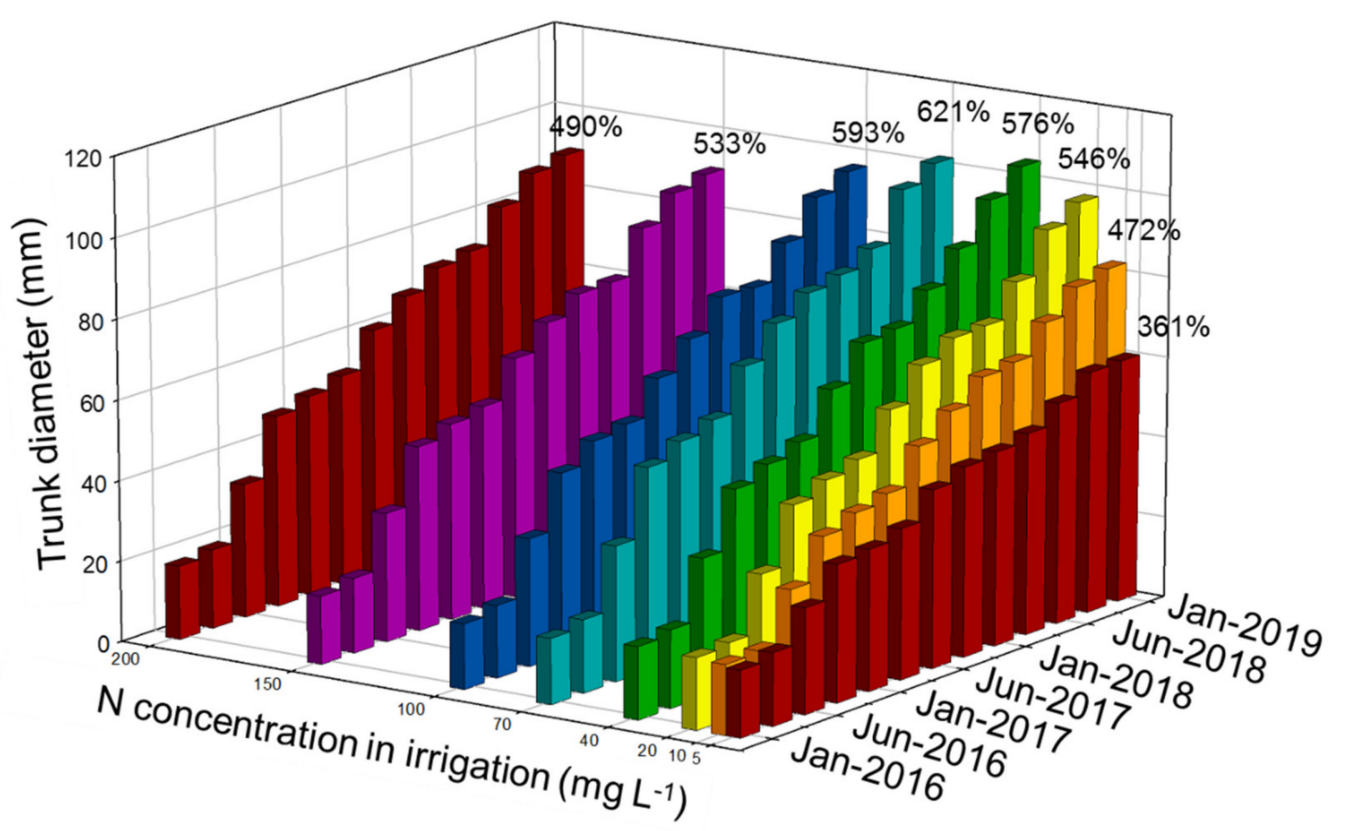

Figure 4. Changes of trunk diameter in pomegranate trees under different nitrogen levels. Numbers on the graph are the proportions of trunk diameter increase in January 2019, in relation to the first measurement (January 2016).

Table 1. Annual increase of trunk diameter relative to the previous January.

\begin{tabular}{|c|c|c|c|c|c|c|c|c|}
\hline \multirow{2}{*}{ Periods of Time } & \multicolumn{8}{|c|}{ N Concentration in Irrigation $\left(\mathrm{mg} \mathrm{L}^{-1}\right)$} \\
\hline & 5 & 10 & 20 & 40 & 70 & 100 & 150 & 200 \\
\hline $2016 / 2017$ & $211 \% \mathrm{~d}$ & $249 \%$ c & $281 \%$ bc & $286 \%$ bc & $329 \%$ a & $310 \% \mathrm{ab}$ & $287 \%$ bc & $272 \%$ bc \\
\hline $2017 / 2018$ & $137 \%$ b & $152 \%$ a & $148 \%$ a & $144 \% \mathrm{ab}$ & $148 \%$ a & $150 \%$ a & $145 \% \mathrm{ab}$ & $144 \%$ ab \\
\hline $2018 / 2019$ & $125 \% \mathrm{~b}$ & $125 \% \mathrm{~b}$ & $131 \% \mathrm{ab}$ & $140 \%$ a & $127 \%$ b & $128 \% \mathrm{~b}$ & $128 \% \mathrm{~b}$ & $125 \% \mathrm{~b}$ \\
\hline
\end{tabular}

Different letters represent significant differences between treatments among the same period.

\subsection{Nitrogen Uptake}

Annual $\mathrm{N}$ uptake increased gradually with $\mathrm{N}$ concentration (Table 2). The highest $\mathrm{N}$ uptake was under 200 and $100 \mathrm{mg} \mathrm{N} \mathrm{L}^{-1}$ in 2017 and 2018, respectively. The highest $\mathrm{N}$ uptake ratio and partial factor productivity of applied N (PFP) were found for low N treatment levels during 2017 and 2018. Maximal $\mathrm{N}$ utilization efficiency (NUtE) was calculated for the relatively low $\mathrm{N}$ treatments.

\subsection{Reproduction Indices}

Fruit number was higher in 2018 as compared with 2017 (Table 2). The average yield in 2018 was $112 \%$ higher than in 2017 (73.4 vs. $34.7 \mathrm{~kg}$ per tree, respectively) and the number of fruits per tree doubled, at least, between the years. In 2018, the highest yields were those of trees receiving 40 and $70 \mathrm{mg} \mathrm{N} \mathrm{L}^{-1}$. In both years, the maximal yield was gained in treatments higher than $20 \mathrm{~N} \mathrm{~L}^{-1}$, and an adverse effect was recorded for excessive $\mathrm{N}$ treatment, as the yield of $200 \mathrm{mg} \mathrm{N} \mathrm{L}^{-1}$ treatment was lower than most other levels. 
Table 2. Yield, nitrogen and water during 2017 and 2018.

\begin{tabular}{|c|c|c|c|c|c|c|c|c|c|c|c|}
\hline Year & $\begin{array}{l}\text { N in Irrigation } \\
\left(m g \mathrm{~N} \mathrm{~L}^{-1}\right)\end{array}$ & $\begin{array}{l}\text { Yield (kg } \\
\left.\text { tree }^{-1}\right)\end{array}$ & $\begin{array}{c}\text { Fruit Per } \\
\text { Tree }\end{array}$ & $\begin{array}{c}\mathrm{N} \text { app. Amount } \\
\left(\mathrm{g} \text { tree }^{-1}\right)\end{array}$ & $\begin{array}{l}\text { N Uptake } \\
\left(\text { g tree }^{-1}\right)\end{array}$ & $\begin{array}{c}\text { N Ratio } \\
\text { Uptake/Application }\end{array}$ & $\begin{array}{l}\text { PFP (kg } \\
\left.\text { kg }^{-1}\right)\end{array}$ & $\begin{array}{c}\text { NUtE (kg } \\
\text { kg-1) }^{-1}\end{array}$ & $\begin{array}{c}\text { Volume of } \\
\text { Irrigation }\left(\mathrm{m}^{3}\right. \\
\left.\text { tree }^{-1}\right)\end{array}$ & $\begin{array}{c}\text { WUE (kg } \\
\left.\mathbf{m}^{-3}\right)\end{array}$ & $\begin{array}{c}\text { WUpE (kg } \\
\left.\mathbf{m}^{-3}\right)\end{array}$ \\
\hline \multirow{8}{*}{2017} & 5 & $3.4 \mathrm{c}$ & $7 \mathrm{c}$ & 33 & $27 \mathrm{f}$ & $0.81 \mathrm{a}$ & $101.2 \mathrm{bc}$ & $124 \mathrm{~b}$ & 6.6 & $0.51 \mathrm{c}$ & $1.25 \mathrm{c}$ \\
\hline & 10 & $19.4 \mathrm{~b}$ & $34 \mathrm{~b}$ & 121 & $104 \mathrm{ef}$ & $0.86 \mathrm{a}$ & $160.2 \mathrm{a}$ & $186 \mathrm{a}$ & 12.1 & $1.60 \mathrm{~b}$ & $3.03 \mathrm{~b}$ \\
\hline & 20 & $43.4 \mathrm{a}$ & $75 a$ & 309 & 255 de & $0.82 \mathrm{a}$ & $140.3 \mathrm{ab}$ & $170 \mathrm{ab}$ & 15.5 & $2.81 \mathrm{a}$ & $4.66 \mathrm{a}$ \\
\hline & 40 & $48.2 \mathrm{a}$ & $80 \mathrm{a}$ & 623 & $355 \mathrm{~d}$ & $0.57 \mathrm{~b}$ & $77.4 \mathrm{~cd}$ & $139 a b$ & 15.6 & $3.09 \mathrm{a}$ & $4.14 \mathrm{ab}$ \\
\hline & 70 & $43.6 \mathrm{a}$ & $75 \mathrm{a}$ & 1203 & $694 \mathrm{c}$ & $0.58 \mathrm{~b}$ & $36.3 \mathrm{de}$ & $63 c$ & 17.2 & $2.54 \mathrm{a}$ & $4.25 \mathrm{ab}$ \\
\hline & 100 & $38.2 \mathrm{a}$ & $65 a$ & 1588 & 822 bc & $0.52 \mathrm{~b}$ & $24.1 \mathrm{e}$ & $47 \mathrm{c}$ & 15.9 & $2.41 \mathrm{ab}$ & $3.72 \mathrm{ab}$ \\
\hline & 150 & $44.9 \mathrm{a}$ & $77 \mathrm{a}$ & 2305 & $957 \mathrm{ab}$ & $0.42 \mathrm{c}$ & $19.5 \mathrm{e}$ & $48 \mathrm{c}$ & 15.4 & $2.92 \mathrm{a}$ & $4.5 \mathrm{ab}$ \\
\hline & 200 & $36.8 \mathrm{a}$ & $66 \mathrm{a}$ & 2737 & $1037 \mathrm{a}$ & $0.38 \mathrm{c}$ & $13.4 \mathrm{e}$ & $38 \mathrm{c}$ & 13.7 & $2.69 \mathrm{a}$ & $4.74 \mathrm{a}$ \\
\hline \multirow{8}{*}{2018} & 5 & $15.8 \mathrm{~d}$ & $29 c$ & 48 & $48 \mathrm{e}$ & $1.00 \mathrm{a}$ & 333.3 a & $333 a$ & 9.5 & $1.67 \mathrm{c}$ & $3.95 \mathrm{e}$ \\
\hline & 10 & $51.2 \mathrm{c}$ & $85 \mathrm{~b}$ & 179 & $179 \mathrm{e}$ & $1.00 \mathrm{a}$ & $287.7 \mathrm{a}$ & $287 a$ & 17.8 & $2.88 \mathrm{~b}$ & $5.57 \mathrm{bcd}$ \\
\hline & 20 & $89.0 \mathrm{ab}$ & $147 \mathrm{a}$ & 502 & $468 \mathrm{~d}$ & $0.93 \mathrm{a}$ & $177.3 \mathrm{~b}$ & $190 \mathrm{~b}$ & 25.1 & $3.55 \mathrm{ab}$ & $5.96 \mathrm{abc}$ \\
\hline & 40 & $92.8 \mathrm{ab}$ & $159 a$ & 1170 & 801 bc & $0.69 \mathrm{~b}$ & $79.3 \mathrm{c}$ & $118 \mathrm{bc}$ & 29.2 & $3.17 \mathrm{ab}$ & 4.9 cde \\
\hline & 70 & $97.3 \mathrm{a}$ & $177 \mathrm{a}$ & 2065 & $749 c$ & $0.36 \mathrm{~d}$ & $47.1 \mathrm{c}$ & $131 \mathrm{bc}$ & 29.5 & $3.30 \mathrm{ab}$ & $5.18 \mathrm{cde}$ \\
\hline & 100 & $79.8 \mathrm{ab}$ & $137 \mathrm{a}$ & 2824 & $1294 \mathrm{a}$ & $0.46 \mathrm{c}$ & $28.3 c$ & $64 c$ & 28.2 & $2.83 \mathrm{~b}$ & $4.39 \mathrm{de}$ \\
\hline & 150 & $89.8 \mathrm{ab}$ & $177 \mathrm{a}$ & 3549 & 922 bc & $0.26 \mathrm{e}$ & $25.3 c$ & $100 \mathrm{c}$ & 23.7 & $3.79 \mathrm{a}$ & $7.44 \mathrm{a}$ \\
\hline & 200 & $71.6 \mathrm{bc}$ & $140 \mathrm{a}$ & 3991 & $947 \mathrm{~b}$ & $0.24 \mathrm{e}$ & $17.9 \mathrm{c}$ & $78 \mathrm{c}$ & 20.0 & $3.59 \mathrm{ab}$ & $7.03 \mathrm{ab}$ \\
\hline
\end{tabular}

$\mathrm{N}$ ratio $=\mathrm{N}$ uptake/N application; PFP, partial factor productivity of applied $\mathrm{N}=$ fruit yield/N application amount; NUtE, $\mathrm{N}$ utilization efficiency = fruit yield/N uptake amount; WUpE, water uptake efficiency $=$ fruit yield/volume of water consumption; WUE, water use efficiency = fruit yield/volume of irrigation. The period of 2017 was from November 2016 to October 2017 and the period of 2018 was from November 2017 to October 2018 


\section{Discussion}

Many studies over the last years have demonstrated the qualitative and quantitative influence of $\mathrm{N}$ fertilization on fruit trees $[19,35,36]$. Our work revealed that $\mathrm{N}$ is indeed essential for pomegranate development, but when considering vegetative and reproductive indices, there is a point from which elevated $\mathrm{N}$ restrained tree development. We found response curves with maximum and optimum values at mid-level $\mathrm{N}$ treatments and reductions due to high $\mathrm{N}$ exposure (Figures 3 and 4 ). Some of the indices we checked are renewed yearly, for example, canopy volume, leaf density and area, and pruning material weight. Others, such as trunk growth, represent progressive status.

In our experiment, low $\mathrm{N}$ resulted in small, light-green blades, while in the excessive $\mathrm{N}$ treatments, the leaves were larger and darker (Figure 2). This finding is in line with the literature, as $\mathrm{N}$ deficiency in pomegranate is known to cause leaf yellowing and reduction in shoot growth and yield [28]. Although $\mathrm{N}$ concentration in the irrigation water of each treatment was constant throughout the year, $\mathrm{N}$ concentration in leaves was lower in September as compared with May, during the three years of the experiment (Figure 1). Foliar $\mathrm{N}$ of deciduous trees is known to be translocated before fall [37]. The decrease in its level in our experiment was expected, due to accelerated growth, measured as trunk diameter, between April and October (Figure 4), and the high sink of fruit during the autumn. Fluctuations in leaf $\mathrm{N}$ content in correlation with reproduction were reported in other fruit trees, such as almond [38], olive [39,40], and avocado [41]. It is noticeable that $\mathrm{N}$ concentration in diagnostic leaves was highest in 2018 (Figure 1), although the treatment was constant during all the years. The latter could indicate the translocation of $\mathrm{N}$ from tree reserves or reflect higher $\mathrm{N}$ uptake, due to excessive vegetative growth. This issue should be studied separately. $\mathrm{N}$ leaf content was not changed significantly in treatments higher than 20 to $40 \mathrm{mg} \mathrm{N} \mathrm{L}^{-1}$, and we assume that this is the known insensitivity of this analysis method to excessive $\mathrm{N}$ conditions [14,42], which could be explained by transportation of excessive $\mathrm{N}$ to the tree's roots (18). It seems that diagnostic leaf analysis cannot be a single method to rely on when high $\mathrm{N}$ is suspected. Chlorophyll content, which is another method of evaluating $\mathrm{N}$ level in the leaves [43], was analyzed from 2016 to 2018 (Figure 2). The different $\mathrm{N}$ levels gave distinct results each year, with greater diversity between the treatments in 2017 and 2018, in which the trees bore fruit. The partial factor productivity of applied N (PFP), which is a N efficiency index [44], was found to be synchronized with the annual growth of pear trees and highly correlated with $\mathrm{N}$ availability in the root zone [45]. However, in our experiment, $\mathrm{N}$ availability was consistently high due to the soilless media and excessive irrigation; hence, growth cycle had a greater impact over this parameter. $\mathrm{N}$ use efficiency (NUE) is known to be high at low $\mathrm{N}$ supplies, due to changes in $\mathrm{N}$ metabolism of the plant under such conditions [46]. N-starved roots have a higher capacity of active $\mathrm{N}$ uptake due to the molecular regulation of $\mathrm{N}$ transporters [47]. High NUE is a desired goal and should be considered together with growth and reproduction. In 2018, around three-quarters of the $\mathrm{N}$ in the high-level treatments were not taken up by trees, but rather transferred out of the system via drainage (Table 2).

In terms of yield, $20 \mathrm{mg} \mathrm{N} \mathrm{L}^{-1}$ was sufficient, and higher concentrations had no significant additional impact (Table 2). This result is strengthened by the fact that $\mathrm{N}$ concentration in the leaves of trees receiving $20 \mathrm{mg} \mathrm{N} \mathrm{L}^{-1}$ was within the $14-20 \mathrm{mg} \mathrm{g}^{-1}$ range considered optimal [48]. The lower treatment, $10 \mathrm{mg} \mathrm{N} \mathrm{L}^{-1}$, resulted in poor $\mathrm{N}$ leaf concentration, below the assumed optimal range (Figure 1). High $\mathrm{N}$ concentration was not only unnecessary but also detrimental to tree development, as displayed in the performance of trees receiving $200 \mathrm{mg} \mathrm{N} \mathrm{L}^{-1}$. This impairment could be due to photosynthesis insufficiencies, as found in almonds [18]. In our experiment, the density of the trees was of 625 per hectare, but commercial orchards are of diverse densities, for example, in Israel 333 to 417 trees per hectare [23,49], in Egypt 400 [50], in Spain 500 [51], in California 567 [29], and in Afghanistan 285 to 666 trees per hectare [28]. Due to this diversity, and considering the intensive production system, we prefer to quantify the data per tree and not per hectare. During 2018, the minimal treatment that gave optimal yield ( $89 \mathrm{~kg}$ per tree) was that of $20 \mathrm{mg} \mathrm{N} \mathrm{L}^{-1}$ (Table 2). The trees in this treatment consumed $25.1 \mathrm{~m}^{3}$ water per tree. They received $502 \mathrm{~g} \mathrm{~N}$, and the uptake was $93 \%$ of $468 \mathrm{~g} \mathrm{~N}$ for each tree. Figure 5 summarizes the 2017 and 2018 results and demonstrates that $\mathrm{N}$ efficiency behaves 
conversely to $\mathrm{N}$ uptake, as the highest pomegranate yield was obtained under $\mathrm{N}$ concentrations between 20 and $70 \mathrm{mg} \mathrm{L}^{-1}$.

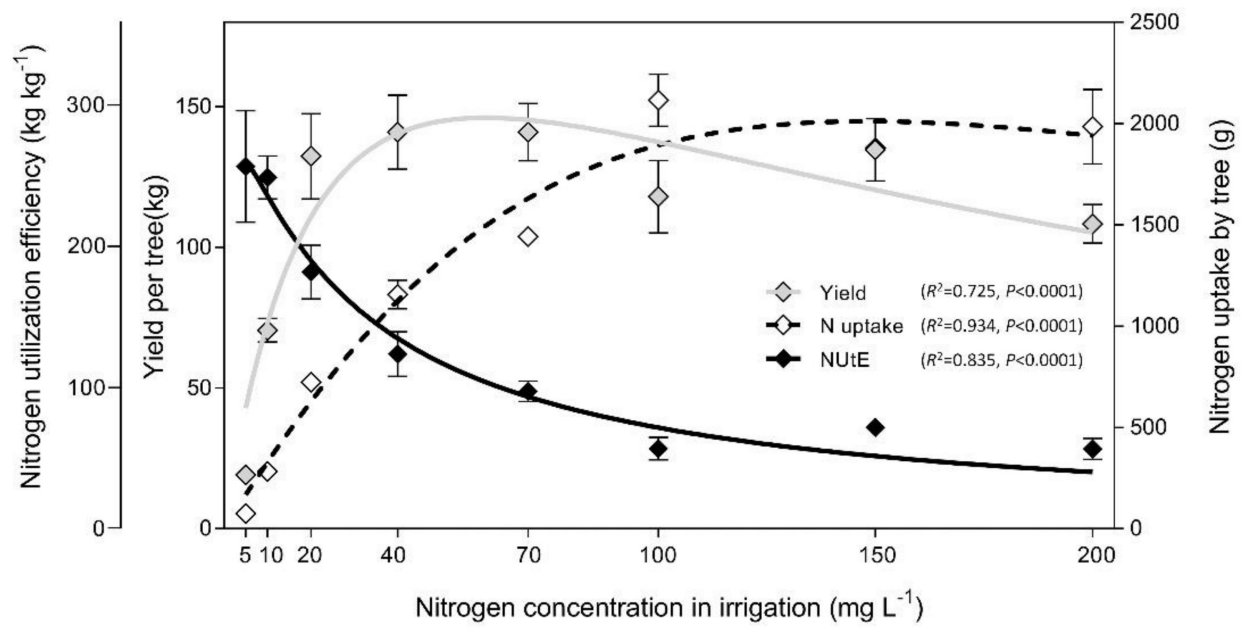

Figure 5. The effect of nitrogen levels on yield, $\mathrm{N}$ uptake and $\mathrm{N}$ utilization efficiency of pomegranates over two years (a combination of 2017 and 2018). Bars represent SD. Regression equations and statistics are presented in Table A1. Significance between treatments is presented in Table A2.

Fertigation management allows the development of a compact root system following frequent and constant water application [52] and high $\mathrm{N}$ efficiency due to accumulation in the wetted irrigation bulb [53]. Using this kind of system can result, on the one hand, in exploiting growth and reproduction potential and, on the other, minimizing groundwater pollution by nitrates.

To conclude, we found that $\mathrm{N}$ concentration in diagnostic leaves reached maximum values at irrigation levels of 40 to $70 \mathrm{mg} \mathrm{N} \mathrm{L}^{-1}$, and cannot be used for the identification of excessive $\mathrm{N}$. This was also the case with chlorophyll content diagnosis of the leaves. A N supply of 20 to $70 \mathrm{mg} \mathrm{L}^{-1}$ gained the optimal vegetative and reproductive indices, while higher levels reduced growth and yield. This study is the first time that the actual value of $\mathrm{N}$ consumption per bearing pomegranate tree is given. As fertilization is a fundamental, resource-intensive agronomic routine, this value can be useful for planning the crop's fertilization regime, increasing NUE and diminishing $\mathrm{N}$ losses in the environment. Nevertheless, our trees were grown in perlite, meaning nearly the maximum possible transport of $\mathrm{N}$ to roots with the water and roughly optimal conditions for its uptake. Orchards planted in soil depend on more complex water flow and transport, and these factors make uptake significantly less efficient. The results demonstrate the pomegranate plant's reaction to elevated $\mathrm{N}$ levels, rather than recommend an applicative regime. These data can be used as an elementary basis for pomegranate intensive cultivation interface. However, further steps are required to validate and convert the findings into horticultural recommendations.

Author Contributions: Conceptualization, U.Y., A.D. and A.B.-G.; methodology, U.Y., A.D., A.B.-G. and D.H.; validation, U.Y. and A.D.; resources and funding acquisition, A.D. and U.Y.; investigation and data curation, Y.L. and Y.H.; formal analysis, Y.L., S.L. and U.Y.; writing-original draft preparation, S.L.; writing-review and editing, Y.L., U.Y., D.H., A.B.-G. and A.D.; visualization, S.L. and Y.L.; supervision and project administration, A.D. All authors have read and agreed to the published version of the manuscript.

Funding: This research was funded by the Chief Scientist of the Israel Ministry of Agriculture \& Rural Development, grant number 20-10-0030, and by the Center of Fertilization and Plant Nutrition (CFPN).

Acknowledgments: We thank Yonatan Ron, Gregory Mishiev, Inna Faingold, Riva Gavrilov, Talal Hawashla, and Yulia Subbotin for technical support in the field and laboratory.

Conflicts of Interest: The authors declare no conflict of interest. The funders had no role in the design of the study; in the collection, analyses, or interpretation of data; in the writing of the manuscript, or in the decision to publish the results. 


\section{Appendix A}

Table A1. Regression equations and statistics for Figures 1-3 and 5.

\begin{tabular}{|c|c|c|c|c|c|}
\hline Figure & Parameter & Year or Month & Equation $(Y=\ldots)$ & $\mathbf{R}^{2}$ & $P$ \\
\hline \multirow{2}{*}{$1 \mathrm{~A}$} & \multirow{6}{*}{ Leaf $\mathrm{N}$ concentration } & 2016-May & $16.65 X /(2.502+X(1+X / 1.421 e 157))$ & 0.6104 & $<0.0001$ \\
\hline & & 2016-Sept. & $14.11 X /(3.769+X(1+X / 58853))$ & 0.7716 & $<0.0001$ \\
\hline \multirow{2}{*}{$1 \mathrm{~B}$} & & 2017-May & $22.3 X /(6.561+X(1+X / 9244))$ & 0.8788 & $<0.0001$ \\
\hline & & 2017-Sept. & $18.18 X /(5.233+X(1+X / 1083))$ & 0.6329 & $<0.0001$ \\
\hline \multirow{2}{*}{$1 \mathrm{C}$} & & 2018-May & $20.54 X /(4.218+X(1+X / 4.115 e 139))$ & 0.8169 & $<0.0001$ \\
\hline & & 2018-Sept. & $18.47 X /(4.016+X(1+X / 48734))$ & 0.7763 & $<0.0001$ \\
\hline \multirow{3}{*}{$2 \mathrm{~A}$} & \multirow{3}{*}{ Leaf chlorophyll content } & 2016 & $64.44 X /(4.083+X(1+X / 1.028 e 104))$ & 0.8656 & $<0.0001$ \\
\hline & & 2017 & $62.33 X /(5.287+X(1+X / 6403))$ & 0.9335 & $<0.0001$ \\
\hline & & 2018 & $68.16 \mathrm{X} /(2.86+\mathrm{X}(1+\mathrm{X} / 1.314 e 92))$ & 0.8459 & $<0.0001$ \\
\hline \multirow{2}{*}{$3 \mathrm{~A}$} & \multirow{2}{*}{ Canopy volume } & 2017 & $16.46 \mathrm{X} /(24.93+\mathrm{X}(1+\mathrm{X} / 131.7))$ & 0.7059 & $<0.0001$ \\
\hline & & 2018 & $69.74 X /(42.18+X(1+X / 54.29))$ & 0.7463 & $<0.0001$ \\
\hline \multirow{2}{*}{$3 \mathrm{~B}$} & \multirow{2}{*}{ Pruning branch weight } & 2017 & $1434 X /(32798+X(1+X / 0.09584))$ & 0.4641 & $<0.0001$ \\
\hline & & 2018 & $8922 X /(22432+X(1+X / 0.1446))$ & 0.5911 & $<0.0001$ \\
\hline \multirow{3}{*}{$3 C$} & \multirow{3}{*}{ Leaf density } & 2016 & $5.775 X /(5.346+X(1+X / 516.2))$ & 0.4807 & $<0.0001$ \\
\hline & & 2017 & $13.47 X /(14.42+X(1+X / 219.3))$ & 0.8860 & $<0.0001$ \\
\hline & & 2018 & $11.17 X /(5.542+X(1+X / 429.9))$ & 0.6508 & $<0.0001$ \\
\hline \multirow{3}{*}{$3 \mathrm{D}$} & \multirow{3}{*}{$\begin{array}{l}\text { Annual accumulated } \\
\text { water consumption }\end{array}$} & 2016 & $13.33 X /(29.61+X(1+X / 65.26))$ & 0.8095 & $<0.0001$ \\
\hline & & 2017 & $21.75 X /(25.09+X(1+X / 124))$ & 0.9315 & $<0.0001$ \\
\hline & & 2018 & $105.2 X /(107.1+X(1+X / 23.58))$ & 0.9417 & $<0.0001$ \\
\hline \multirow{3}{*}{5} & \multirow{3}{*}{$\begin{array}{c}\text { Fruit yield } \\
\text { Nitrogen uptake } \\
\text { Nitrogen utilization } \\
\text { efficiency }\end{array}$} & $2017-18$ & $279 X /(27.35+X(1+X / 132.2))$ & 0.7248 & $<0.0001$ \\
\hline & & $2017-18$ & $10002 X /(293.8+X(1+X / 74.46))$ & 0.9336 & $<0.0001$ \\
\hline & & 2017-18 & $167.5 X /(0.4928+X(1+X / 27.31))$ & 0.8354 & $<0.0001$ \\
\hline
\end{tabular}

Table A2. Significance for Figures 1-3 and 5.

\begin{tabular}{|c|c|c|c|c|c|c|c|c|c|c|}
\hline Figure & Parameter & $\begin{array}{l}\text { Year or } \\
\text { Month }\end{array}$ & 5 & 10 & 20 & 40 & 70 & 100 & 150 & 200 \\
\hline \multirow{2}{*}{$1 \mathrm{~A}$} & \multirow{6}{*}{ Leaf $N$ concentration } & 2016-May & $\mathrm{f}$ & $\mathrm{d}$ & c & $\mathrm{bc}$ & $a b$ & $a b$ & $\mathrm{ab}$ & a \\
\hline & & 2016-Sept. & $\mathrm{c}$ & $c$ & $\mathrm{~b}$ & $a b$ & $a b$ & $a b$ & $\mathrm{ab}$ & a \\
\hline \multirow{2}{*}{$1 \mathrm{~B}$} & & 2017-May & $\mathrm{f}$ & $\mathrm{e}$ & $\mathrm{d}$ & $\mathrm{cd}$ & $a b$ & $\mathrm{~cd}$ & $\mathrm{bc}$ & a \\
\hline & & 2017-Sept. & c & $b$ & a & $\mathrm{a}$ & $a b$ & $\mathrm{a}$ & $\mathrm{a}$ & a \\
\hline \multirow{2}{*}{$1 \mathrm{C}$} & & 2018-May & $\mathrm{d}$ & $\mathrm{d}$ & c & $\mathrm{bc}$ & $a b$ & c & $\mathrm{bc}$ & a \\
\hline & & 2018-Sept. & $\mathrm{d}$ & $c$ & $\mathrm{~b}$ & $\mathrm{~b}$ & $a b$ & $\mathrm{~b}$ & $\mathrm{ab}$ & a \\
\hline \multirow{3}{*}{$2 \mathrm{~A}$} & \multirow{3}{*}{ Leaf chlorophyll content } & 2016 & $\mathrm{~d}$ & $\mathrm{c}$ & $\mathrm{b}$ & $\mathrm{b}$ & $\mathrm{a}$ & $b$ & a & $\mathrm{a}$ \\
\hline & & 2017 & $\mathrm{f}$ & $\mathrm{e}$ & $\mathrm{d}$ & $c$ & $\mathrm{bc}$ & $a b c$ & a & $\mathrm{ab}$ \\
\hline & & 2018 & $\mathrm{~d}$ & $\mathrm{~d}$ & c & $\mathrm{bc}$ & $a b$ & $\mathrm{ab}$ & $\mathrm{ab}$ & a \\
\hline \multirow{2}{*}{$3 \mathrm{~A}$} & \multirow{2}{*}{ Canopy volume } & 2017 & $\mathrm{~d}$ & $\mathrm{c}$ & $\mathrm{ab}$ & $\mathrm{ab}$ & a & $\mathrm{ab}$ & $\mathrm{b}$ & $b$ \\
\hline & & 2018 & $\mathrm{e}$ & d & $a b c$ & $\mathrm{a}$ & $a b$ & bc & bc & $\mathrm{cd}$ \\
\hline \multirow{2}{*}{$3 \mathrm{~B}$} & \multirow{2}{*}{ Pruning branch weight } & 2017 & $\mathrm{~d}$ & $\mathrm{~cd}$ & $\mathrm{bc}$ & a & $a b$ & $a b$ & bc & $a b c$ \\
\hline & & 2018 & $\mathrm{e}$ & de & $\mathrm{b}$ & $\mathrm{bc}$ & $\mathrm{a}$ & $a b$ & $\mathrm{~cd}$ & $\mathrm{~cd}$ \\
\hline \multirow{3}{*}{$3 C$} & \multirow{3}{*}{ Leaf density } & 2016 & $\mathrm{~d}$ & $\mathrm{bc}$ & $\mathrm{bc}$ & $\mathrm{a}$ & a & $\mathrm{b}$ & $\mathrm{bc}$ & $\mathrm{ab}$ \\
\hline & & 2017 & $\mathrm{e}$ & $\mathrm{d}$ & $\mathrm{bc}$ & $\mathrm{ab}$ & a & c & $\mathrm{c}$ & c \\
\hline & & 2018 & $\mathrm{~d}$ & c & c & $\mathrm{a}$ & $a b$ & bc & c & c \\
\hline \multirow{3}{*}{$3 \mathrm{D}$} & \multirow{3}{*}{$\begin{array}{l}\text { Annual accumulated water } \\
\text { consumption }\end{array}$} & 2016 & $\mathrm{e}$ & $\mathrm{d}$ & $\mathrm{b}$ & $\mathrm{b}$ & $\mathrm{a}$ & c & $\mathrm{c}$ & c \\
\hline & & 2017 & $\mathrm{f}$ & e & c & $\mathrm{a}$ & $\mathrm{b}$ & $\mathrm{b}$ & $\mathrm{bc}$ & $\mathrm{d}$ \\
\hline & & 2018 & $\mathrm{e}$ & d & $\mathrm{b}$ & a & a & a & c & $\mathrm{d}$ \\
\hline \multirow{3}{*}{5} & Fruit yield & 2017-18 & $\mathrm{d}$ & c & $\mathrm{ab}$ & a & a & $a b$ & $\mathrm{ab}$ & $\mathrm{b}$ \\
\hline & Nitrogen uptake & 2017-18 & $\mathrm{e}$ & e & $\mathrm{d}$ & c & $\mathrm{b}$ & $\mathrm{a}$ & $\mathrm{a}$ & a \\
\hline & Nitrogen utilization efficiency & 2017-18 & $\mathrm{a}$ & $\mathrm{a}$ & $\mathrm{b}$ & c & $\mathrm{cd}$ & $\mathrm{d}$ & $\mathrm{cd}$ & $\mathrm{d}$ \\
\hline
\end{tabular}




\section{References}

1. Bernardi, A.C.D.C.; Carmello, Q.A.D.C.; Carvalho, S.A.D.; Machado, E.C.; Medina, C.L.; Gomes, M.D.M.D.A.; Lima, D.M. Nitrogen, phosphorus and potassium fertilization interactions on the photosynthesis of containerized citrus nursery trees. J. Plant. Nutr. 2015, 38, 1902-1912. [CrossRef]

2. Bonner, J.; Varner, J.E. Plant Biochemistry; Academic Press: New York, NY, USA, 2012.

3. Lea, P.J.; Morot-Gaudry, J.F. Plant Nitrogen; Springer Science \& Business Media and INRA: Paris, France, 2013.

4. Lin, Y.L.; Tsay, Y.F. Influence of differing nitrate and nitrogen availability on flowering control in Arabidopsis. J. Exp. Bot. 2017, 68, 2603-2609. [CrossRef] [PubMed]

5. Huett, D. Prospects for manipulating the vegetative-reproductive balance in horticultural crops through nitrogen nutrition: A review. Aust. J. Agric. Res. 1996, 47, 47-66. [CrossRef]

6. Natale, W.; Rozane, D.E.; de Medeiros Corrêa, M.C.; Parent, L.E.; de Deus, J.A.L. Diagnosis and management of nutrient constraints in guava. Fruit Crop. 2020, 711-722.

7. Zipori, I.; Erel, R.; Yermiyahu, U.; Ben-Gal, A.; Dag, A. Sustainable Management of Olive Orchard Nutrition: A Review. Agriculture 2020, 10, 11. [CrossRef]

8. De Araujo, Q.R.; De, A.; Loureiro, G.A.; Ahnert, D.; Escalona-Valdez, R.A.; Baligar, V.C. Interactions between Soil, Leaves and Beans Nutrient Status and Dry Biomass of Beans and Pod Husk of Forastero Cacao: An Exploratory Study. Commu. Soil Sci. Plant Anal. 2020, 1-15.

9. Zhai, Y.; Lei, Y.; Wu, J.; Teng, Y.; Wang, J.; Zhao, X.; Pan, X. Does the groundwater nitrate pollution in China pose a risk to human health? A critical review of published data. Environ. Sci.. Pollut. Res. 2017, 24, 3640-3653. [CrossRef]

10. Zhai, Y.; Zhao, X.; Teng, Y.; Li, X.; Zhang, J.; Wu, J.; Zuo, R. Groundwater nitrate pollution and human health risk assessment by using HHRA model in an agricultural area, NE China. Ecotoxicol. Environ. Saf. 2017, 137, 130-142. [CrossRef]

11. Baram, S.; Couvreur, V.; Harter, T.; Read, M.; Brown, P.; Kandelous, M.; Smart, D.R.; Hopmans, J.W. Estimating nitrate leaching to groundwater from orchards: Comparing crop nitrogen excess, deep vadose zone data-driven estimates, and HYDRUS modeling. Vadose Zone J. 2016, 15. [CrossRef]

12. Boyle, E. Nitrogen pollution knows no bounds. Science 2017, 356, 700-701. [CrossRef]

13. Cameira, M.; Mota, M. Nitrogen related diffuse pollution from horticulture production-mitigation practices and assessment strategies. Horticulturae 2017, 3, 25. [CrossRef]

14. Erel, R.; Yermiyahu, U.; Van Opstal, J.; Ben-Gal, A.; Schwartz, A.; Dag, A. The importance of olive (Olea europaea L.) tree nutritional status on its productivity. Sci. Hortic. 2013, 159, 8-18. [CrossRef]

15. Fernández-Escobar, R. Use and abuse of nitrogen in olive fertilization. Acta Hortic. 2011, 888, $249-257$. [CrossRef]

16. Zaman, Q.; Schumann, A.; Miller, W. Variable rate nitrogen application in Florida citrus based on ultrasonically-sensed tree size. Appl. Eng. Agric. 2005, 21, 331-335. [CrossRef]

17. Nava, G.; Dechen, A.R.; Nachtigall, G.R. Nitrogen and potassium fertilization affect apple fruit quality in southern Brazil. Commun. Soil Sci. Plant Anal. 2007, 39, 96-107. [CrossRef]

18. Sperling, O.; Karuanakaran, R.; Erel, R.; Yasuor, H.; Klipcan, L.; Yermiyahu, U. Excessive nitrogen impairs hydraulics, limits photosynthesis, and alters the metabolic composition of almond trees. Plant Physiol. Biochem. 2019, 143, 265-274. [CrossRef] [PubMed]

19. Haberman, A.; Dag, A.; Shtern, N.; Zipori, I.; Erel, R.; Ben-Gal, A.; Yermiyahu, U. Significance of proper nitrogen fertilization for olive productivity in intensive cultivation. Sci. Hortic. 2019, 246, 710-717. [CrossRef]

20. Muñoz-Huerta, R.; Guevara-Gonzalez, R.; Contreras-Medina, L.; Torres-Pacheco, I.; Prado-Olivarez, J.; Ocampo-Velazquez, R. A review of methods for sensing the nitrogen status in plants: Advantages, disadvantages and recent advances. Sensors 2013, 13, 10823-10843.

21. Babu, D. Floral biology of pomegranate (Punica granatum L.). Pomegranate 2010, 4, 45-50.

22. Romano, K.R.; Finco, F.D.B.A.; Rosenthal, A.; Finco, M.V.A.; Deliza, R. Willingness to pay more for value-added pomegranate juice (Punica granatum L.): An open-ended contingent valuation. Food Res. Int. 2016, 89, 359-364. [CrossRef]

23. Holland, D.; Hatib, K.; Bar-Ya'akov, I. Pomegranate: Botany, Horticulture, Breeding. Hortic. Rev. 2009, 35 , 127-191. 
24. Venkataramudu, K.; Naik, S.R.; Viswanath, M.; Chandramohan, G. Packaging and storage of pomegranate fruits and arils: A review. Int. J. Chem. 2018, 6, 1964-1967.

25. Rodríguez, P.; Mellisho, C.; Conejero, W.; Cruz, Z.; Ortuno, M.; Galindo, A.; Torrecillas, A. Plant water relations of leaves of pomegranate trees under different irrigation conditions. Environ. Exp. Bot. 2012, 77, 19-24. [CrossRef]

26. Sulochanamma, B.; Yellamanda Reddy, T.; Subbi Reddy, G. Effect of basin and drip irrigation on growth, yield and water use efficiency in pomegranate cv. Ganesh. Acta Hortic. 2005, 696, 277-279. [CrossRef]

27. Mellisho, C.; Egea, I.; Galindo, A.; Rodríguez, P.; Rodríguez, J.; Conejero, W.; Romojaro, F.; Torrecillas, A. Pomegranate (Punica granatum L.) fruit response to different deficit irrigation conditions. Agric. Water Manag. 2012, 114, 30-36. [CrossRef]

28. Glozer, K.; Ferguson, L. Pomegranate Production in Afghanistan; UCDAVIS College of Agricultural and Environmental Sciences: Davis, CA, USA, 2008.

29. Ayars, J.E.; Phene, C.J.; Phene, R.C.; Gao, S.; Wang, D.; Day, K.R.; Makus, D.J. Determining pomegranate water and nitrogen requirements with drip irrigation. Agric. Water Manag. 2017, 187, 11-23. [CrossRef]

30. Carranca, C.; Brunetto, G.; Tagliavini, M. Nitrogen nutrition of fruit trees to reconcile productivity and environmental concerns. Plants 2018, 7, 4. [CrossRef]

31. Dhillon, W.; Gill, P.; Singh, N. Effect of nitrogen, phosphorus and potassium fertilization on growth, yield and quality of pomegranate 'Kandhari'. Acta Hortic. 2011, 890, 327-332. [CrossRef]

32. Wang, D.; Ayars, J.; Tirado-Corbala, R.; Makus, D.; Phene, C.; Phene, R. Water and nitrogen management of young and maturing pomegranate trees; III International Symposium on Pomegranate and Minor. Mediterranean Fruits. ISHS Acta Hortic. 2013, 1089, 395-401.

33. Nerya, O.; Levin, A. Innovative treatment of pomegranates from harvest to market; III International Symposium on Pomegranate and Minor. Mediterranean Fruits. ISHS Acta Hortic. 2013, 1089, 489-493.

34. Easlon, H.M.; Bloom, A.J. Easy Leaf Area: Automated digital image analysis for rapid and accurate measurement of leaf area. Appl. Plant Sci. 2014, 2. [CrossRef] [PubMed]

35. Fallahi, E.; Fallahi, B.; Kiester, M.J. Evapotranspiration-based irrigation systems and nitrogen effects on yield and fruit quality at harvest in fully mature 'Fuji'apple trees over four years. HortScience 2018, 53, 38-43. [CrossRef]

36. Nirgude, V.; Misra, K.; Singh, P.; Singh, A.; Singh, N. NPK fertigation of stone fruit crops: A review. Int. J. Chem. Stud. 2018, 6, 3134-3142.

37. Zhang, L.; Gao, Y.; Zhang, Y.; Liu, J.; Yu, J. Changes in bioactive compounds and antioxidant activities in pomegranate leaves. Sci. Hortic. 2010, 123, 543-546. [CrossRef]

38. Muhammad, S.; Sanden, B.L.; Lampinen, B.D.; Saa, S.; Siddiqui, M.I.; Smart, D.R.; Olivos, A.; Shackel, K.A.; DeJong, T.; Brown, P.H. Seasonal changes in nutrient content and concentrations in a mature deciduous tree species: Studies in almond (Prunus dulcis (Mill.) DA Webb). Eur. J. Agron. 2015, 5, 52-68. [CrossRef]

39. Bustan, A.; Avni, A.; Yermiyahu, U.; Ben-Gal, A.; Riov, J.; Erel, R.; Zipori, I.; Dag, A. Interactions between fruit load and macroelement concentrations in fertigated olive (Olea europaea L.) trees under arid saline conditions. Sci. Hortic. 2013, 152, 44-55. [CrossRef]

40. Stateras, D.C.; Moustakas, N.K. Seasonal changes of macro-and micro-nutrients concentration in olive leaves. J. Plant Nutr. 2018, 41, 186-196. [CrossRef]

41. Lazare, S.; Haberman, A.; Yermiyahu, U.; Erel, R.; Simenski, E.; Dag, A. Avocado rootstock influences scion leaf mineral content. Arch. Agron. Soil Sci. 2019,1-11. [CrossRef]

42. Rubio-Covarrubias, O.A.; Brown, P.H.; Weinbaum, S.A.; Johnson, R.S.; Cabrera, R.I. Evaluating foliar nitrogen compounds as indicators of nitrogen status in Prunus persica trees. Sci. Hortic. 2009, 120, 27-33. [CrossRef]

43. Fox, R.H.; Walthall, C.L. Crop monitoring technologies to assess nitrogen status. Nitrogen Agric. Syst. 2008, 647-674. [CrossRef]

44. Di Gioia, F.; Gonnella, M.; Buono, V.; Ayala, O.; Cacchiarelli, J.; Santamaria, P. Calcium cyanamide effects on nitrogen use efficiency, yield, nitrates, and dry matter content of lettuce. Agron. J. 2017, 109, 354-362. [CrossRef]

45. Neto, C.; Carranca, C.; de Varennes, A.; Oliveira, C.; Clemente, J.; Sobreiro, J. Nitrogen Use Efficiency of Drip-irrigated 'Rocha' Pear Trees. Acta Hortic. 2006, 721, 337. [CrossRef]

46. Xu, G.; Fan, X.; Miller, A.J. Plant nitrogen assimilation and use efficiency. Annu. Rev. Plant Biol. 2012, 63, 153-182. [CrossRef] 
47. Glass, A.D. Nitrogen use efficiency of crop plants: Physiological constraints upon nitrogen absorption. Crit. Rev. Plant Sci. 2003, 22, 453-470. [CrossRef]

48. Kahramanoglu, I.; Usanmaz, S. Pomegranate Production and Marketing; CRC Press: Boca Raton, FL, USA, 2016.

49. Blumenfeld, A.; Shaya, F.; Hillel, R. Cultivation of pomegranate. Options Méd. Ser. 2000, 42, 143-147.

50. Khattab, M.M.; Shaban, A.E.; El-Shrief, A.H.; El-Deen, M.A. Growth and productivity of pomegranate trees under different irrigation levels. I: Vegetative growth and fruiting. J. Hortic. Sci. Ornam. Plants 2011, 3, 194-198.

51. Intrigliolo, D.; Nicolas, E.; Bonet, L.; Ferrer, P.; Alarcón, J.; Bartual, J. Water relations of field grown Pomegranate trees (Punica granatum) under different drip irrigation regimes. Agric. Water Manag. 2011, 98, 691-696. [CrossRef]

52. Quiñones, A.; Martínez-Alcántara, B.; Primo-Millo, E.; Legaz, F. Fertigation: Concept and application in citrus. In Advances in Citrus Nutrition; Springer: Dordrecht, The Netherlands, 2012; pp. 281-301.

53. Gabriel, J.L.; Quemada, M. Water Management for Enhancing Crop Nutrient Use Efficiency and Reducing Losses. In Advances in Research on Fertilization Management of Vegetable Crops; Springer: Dordrecht, The Netherlands, 2017; pp. 247-265.

(C) 2020 by the authors. Licensee MDPI, Basel, Switzerland. This article is an open access article distributed under the terms and conditions of the Creative Commons Attribution (CC BY) license (http://creativecommons.org/licenses/by/4.0/). 